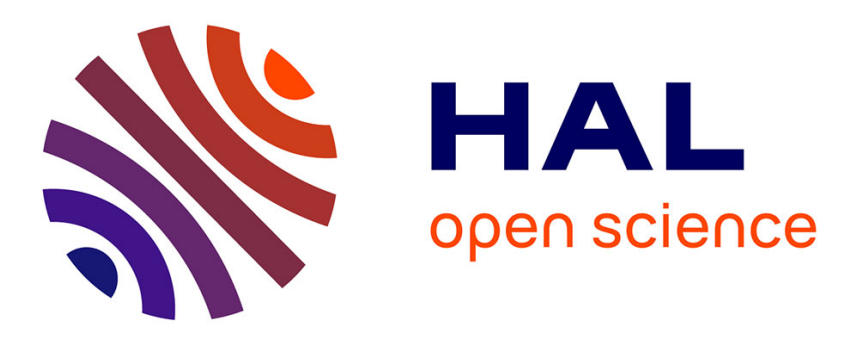

\title{
Triterpenoid saponins and acylated prosapogenins from Harpullia austro-caledonica
}

Laurence Voutquenne, Cécile Kokougan, Catherine Lavaud, Isabelle Pouny, Marc Litaudon

\section{- To cite this version:}

Laurence Voutquenne, Cécile Kokougan, Catherine Lavaud, Isabelle Pouny, Marc Litaudon. Triterpenoid saponins and acylated prosapogenins from Harpullia austro-caledonica. Phytochemistry, 2002, 59 (8), pp.825-832. 10.1016/s0031-9422(01)00482-4 . hal-01996972

HAL Id: hal-01996972

https://hal.univ-reims.fr/hal-01996972

Submitted on 22 Sep 2021

HAL is a multi-disciplinary open access archive for the deposit and dissemination of scientific research documents, whether they are published or not. The documents may come from teaching and research institutions in France or abroad, or from public or private research centers.
L'archive ouverte pluridisciplinaire $\mathbf{H A L}$, est destinée au dépôt et à la diffusion de documents scientifiques de niveau recherche, publiés ou non, émanant des établissements d'enseignement et de recherche français ou étrangers, des laboratoires publics ou privés. 


\section{Triterpenoid saponins and acylated prosapogenins from Harpullia austro-caledonica}

L. Voutquenne*a, C. Kokougan ${ }^{\mathrm{a}}$, C. Lavaud ${ }^{\mathrm{a}}$, I. Pouny ${ }^{\mathrm{b}}$, M. Litaudon ${ }^{\mathrm{c}}$

${ }^{a}$ Laboratoire de Pharmacognosie, UMR CNRS 6013, Bât 18, BP 1039, 51097 Reims Cedex, France. ${ }^{b}$ Institut de Recherche Pierre Fabre - CRSN -UMR CNRS 1973 - 3, rue Ariane, Parc Technologique du Canal - 31257 Ramonville - France.

${ }^{c}$ Laboratoire des plantes médicinales du CNRS - Parc Forestier Montravel, BP 643 - Nouméa Nouvelle Calédonie.

Three bidesmosidic triterpenoid saponins were isolated from the stem bark of Harpullia austro-caledonica and the 24-oxo-camelliagenin D was described. An acylated prosapogenin was characterized in the acid hydrolysis, with two known prosapogenins. The structures were established by spectroscopic methods.

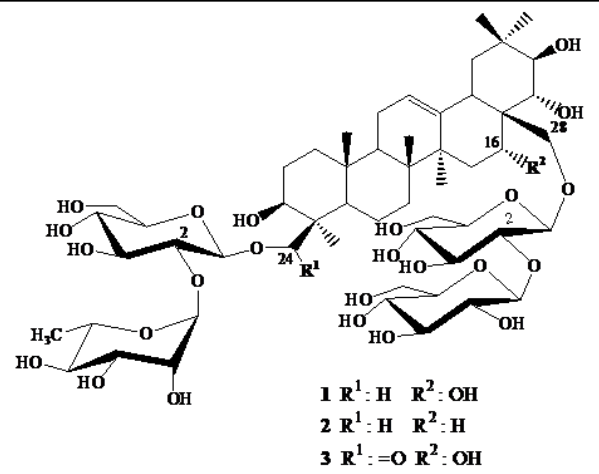




\section{Triterpenoid saponins and acylated prosapogenins from Harpullia}

\section{austro-caledonica}

Laurence Voutquenne*a, Cécile Kokougan ${ }^{\mathrm{a}}$, Catherine Lavaud $^{\mathrm{a}}$, Isabelle Pouny ${ }^{\mathrm{b}}$, Marc Litaudon $^{\mathrm{c}}$

a Laboratoire de Pharmacognosie, UMR CNRS 6013, Bât 18, BP 1039, 51097 Reims Cedex, France.

b Institut de Recherche Pierre Fabre - CRSN -UMR CNRS 1973 - 3, rue Ariane, Parc Technologique du Canal - 31257 Ramonville - France.

${ }^{\mathrm{c}}$ Laboratoire des plantes médicinales du CNRS - Parc Forestier Montravel, BP 643 - Nouméa Nouvelle Calédonie.

\section{* Corresponding author}

Dr. Laurence Voutquenne

Laboratoire de Pharmacognosie

UMR CNRS 6013, Bât 18,

BP 1039

51097 Reims Cedex, France.

Tel : $33(0) 326918208$

Fax : $33(0) 326913596$

E-mail : laurence.voutquenne@univ-reims.fr 
Abstract - Three new triterpenoid saponins have been isolated from the stem bark of Harpullia austro-caledonica and identified as 24-O-[ $\alpha$-L-rhamnopyranosyl-(1->2)- $\beta$-D-glucopyranosyl]-28$O$-[ $\beta$-D-glucopyranosyl-(1->2)- $\beta$-D-glucopyranosyl]-protoaescigenin, 24- $O$-[ $\alpha$-L-rhamnopyranosyl(1->2)- $\beta$-D-glucopyranosyl]-28-O-[ $\beta$-D-glucopyranosyl-(1->2)- $\beta$-D-glucopyranosyl]-16-

desoxyprotoaescigenin, $\quad 24-O$-[ $\alpha$-L-rhamnopyranosyl-(1->2)- $\beta$-D-glucopyranosyl]-28-O-[ $\beta$-Dglucopyranosyl-(1->2)- $\beta$-D-glucopyranosyl]-24-oxo-camelliagenin D. The 21,22-di-O-angeloate esters of protoaescigenin and barringtogenol $\mathrm{C}$ were isolated in the acid hydrolysate of the saponin extract together with a new prosapogenin identified as $21 \beta, 22 \alpha$-di- $O$-angeloyl camelliagenin D. The structures were established using one- and two- dimensional NMR and mass spectrometry. 
Key word index - Harpullia austro-caledonica; Sapindaceae; triterpenoid saponins; protoaescigenin; barringtogenol C; camelliagenin D.

\section{Introduction}

Harpullia austro-caledonica Baillon (Sapindaceae) is a tree or a shrub originating from New Caledonia and growing in the rain forest. In the phylogenetic and taxonomic systems of this genus, this isolated species is next to the most primitive species $H$. pendula and H. arborea (Leenhouts, 1985). The leaves consist of four to seven pairs of leaflets and the inflorescence is composed of yellow unisexual flowers that show an unusually wide range of variability (Leenhouts and Vente, 1982). This species was selected as a part of a screening program for potential cytotoxic compounds from plants collected in New Caledonia. Primary chemical studies showed the presence of alkaloids and saponins. The ethanolic extract from the stem bark of $H$. austro-caledonica exhibited in vitro a cytotoxic activity against $\mathrm{KB}$ cells $(90 \%$ at $10 \mu \mathrm{g} / \mathrm{ml})$. This paper reports on the isolation and structural elucidation of three new and structurally unusual saponins from the stem bark of this plant and of three prosapogenins obtained after acid hydrolysis of saponin crude extract.

\section{Results and discussion}

H. austro-caledonica was collected in the reserve of Amieu Pass and Table Unio in New Caledonia. Dried and powered stem bark was extracted with boiling $80 \%$ methanol and the methanolic extract was concentrated and precipitated into acetone. The crude saponin precipitate was dialysed, chromatographed on a silicagel column and purified by reversed phase C-18 column chromatography. From the most polar fraction, three new compounds $\mathbf{1 , 2}$ and $\mathbf{3}$ were obtained in a pure state after a final purification by preparative TLC. Acid hydrolysis of the saponin extract gave a mixture of three major prosapogenins 4,5 and $\mathbf{6}$ purified by silica gel column chromatography. The sugars were identified by TLC as D-glucose, D-galactose, L-rhamnose, L-arabinose and D- 
xylose.

The positive ESI-MS of saponin 1 gave a quasi-molecular ion peak at $m / z 1161[\mathrm{M}+\mathrm{Na}]^{+}$and in the negative ESI-MS a molecular ion was detected at $\mathrm{m} / z, 1137[\mathrm{M}-\mathrm{H}]^{-}$in agreement with a $\mathrm{M}_{\mathrm{r}}$ of 1138 amu $\left(\mathrm{C}_{54} \mathrm{H}_{90} \mathrm{O}_{25}\right)$. The $\mathrm{MS}^{2}$ experiment of $[\mathrm{M}-\mathrm{H}]^{-}$ion gave negative fragments at $\mathrm{m} / \mathrm{z}, 991$ [M$146]^{-}$and 975 [M-162 $^{-}$attributed to the losses of a terminal 6-desoxy-hexose and a terminal hexose, respectively (Table 1). The $\mathrm{MS}^{3}$ fragmentation of ion at $m / z, 975$ led to ions at $m / z 829$ [M162-146] ${ }^{-}$and 667 [M-162-308 $^{-}$attributed to the losses of the terminal 6-desoxy-hexose and of a disaccharide made of 6-desoxy-hexose and hexose, respectively. The $\mathrm{MS}^{4}$ of ion fragment at $\mathrm{m} / \mathrm{z}$ 829 gave rise to a product ion at $\mathrm{m} / z 505[\text { genin- } \mathrm{H}]^{-}$corresponding to the loss of a third hexose and suggesting a molecular formula of $\mathrm{C}_{30} \mathrm{H}_{50} \mathrm{O}_{6}$ for the aglycone moiety $\left(\mathrm{M}_{\mathrm{r}}\right.$ of $\left.506 \mathrm{amu}\right)$.

Protoaescigenin was identified as the aglycone of saponin $\mathbf{1}$ by analysis of ${ }^{1} \mathrm{H}$ and ${ }^{13} \mathrm{C}-\mathrm{NMR}$ spectra (Table 2) and from observation of connectivities in COSY, HSQC and HMBC spectra. The set of data was in full agreement with those reported in the literature (Chen et al., 1985; Mahato and Kundu, 1994). The ${ }^{1} \mathrm{H}-\mathrm{NMR}$ spectrum showed four methylene protons linked to oxygen bearing carbons which constituted two AX spin systems at $\delta 3.67$ and $4.13(d, J=10 \mathrm{~Hz}, \mathrm{H}-24)$ and at $\delta 3.45$ and $3.66(d, J=10 \mathrm{~Hz}, \mathrm{H}-28)$, two hydroxymethine protons at $\delta 3.27(d d, J=12-4.8 \mathrm{~Hz}, \mathrm{H}-3)$ coupling to two protons at $\delta 1.64$ and 1.76, and at $\delta 4.57$ (brs, $\left.W_{1 / 2}=8 \mathrm{~Hz}, \mathrm{H}-16\right)$ coupling to two protons at $\delta 1.89(d d, J=15-4 \mathrm{~Hz}, \mathrm{H}-15 \mathrm{ax})$ and $1.43(d, J=15 \mathrm{~Hz}, \mathrm{H}-15 \mathrm{eq})$, and two vicinal hydroxymethine protons corresponding to a trans-diequatorial diol which constituted an $\mathrm{AB}$ spin system at $\delta 3.79(d, J=10 \mathrm{~Hz}, \mathrm{H}-22)$ and $3.95(d, J=10 \mathrm{~Hz}, \mathrm{H}-21)$. In the ROESY experiment, the interaction observed between $\mathrm{H}-16$ and $\mathrm{H}-28$ confirmed the $\beta$-equatorial orientation for $\mathrm{H}-16$ and the observation of ROE between $\beta$-axial $\mathrm{H}-2$ at $\delta 1.76$ and $\mathrm{H}-24$ confirmed the configuration of C-4 with a $\beta$-axial orientation for $\mathrm{C}$-24. The $\alpha$-axial orientation of $\mathrm{H}-21$ and the $\beta$-axial position for $\mathrm{H}$ 22 were also confirmed by the ROEs observed with H-29 and H-30, respectively. 
As shown from analysis of ESI-MS, the sugar part of $\mathbf{1}$ consisted of four residues, with anomeric carbons at $\delta 100,101.7,102.4$ and 103.4 in the ${ }^{13} \mathrm{C}$ NMR spectrum, attached to proton doublets at $\delta$ 5.38, 4.23, 4.32 and 4.66 respectively (HSQC exp.). The proton system of each sugar was completely assigned on the basis of COSY and TOCSY experiments (Table 3). The methyl carbon at $\delta 16.9$ which correlated in HSQC spectrum with a methyl proton doublet at $\delta 1.29 \mathrm{ppm}(\mathrm{J}=6 \mathrm{~Hz})$ was assigned to an $\alpha$-L-rhamnose whose anomeric proton appeared as a narrow doublet at $\delta 5.38$ $(J=1.3 \mathrm{~Hz})$. The sugars with their anomeric protons at $\delta 4.23(J=7.7 \mathrm{~Hz}), 4.32(J=7.7 \mathrm{~Hz})$ and 4.66 $(J=7.8 \mathrm{~Hz})$ corresponded to three hexoses with hydroxymethyl carbons at $\delta 61.1,61.4$ and 60.6, respectively, and were identified as three $\beta$-D-glucoses (Table 3). Sequencing of the two sugar chains was achieved by analysis of HMBC and ROESY experiments. HMBC spectrum showed correlations between $\mathrm{C}-28\left(\delta_{\mathrm{C}} 77\right)$ of protoaescigenin and $\mathrm{H}-1$ of a glucose $\left(\delta_{\mathrm{H}} 4.23\right)$ and between C-2 $(\delta 80.3)$ of this glucose and $\mathrm{H}-1\left(\delta_{\mathrm{H}} 4.66\right)$ of a second glucose unit, thus confirming the presence of a sophorose residue attached to C-28 of protoaescigenin. The HMBC cross-peaks observed between $\mathrm{C}-24\left(\delta_{\mathrm{C}} 71.1\right)$ of the protoaescigenin and $\mathrm{H}-1$ of the third glucose unit $\left(\delta_{\mathrm{H}} 4.32\right)$ and between C-1 $(\delta 100)$ of the rhamnose and H-2 of this glucose $\left(\delta_{\mathrm{H}} 3.41\right)$, allowed to locate a neohesperidosyl chain at C-24 of the aglycone. The C-3 position of the protoaescigenin part was not substituted as proven by its carbon chemical shift at $\delta 79$ (Chen et al., 1985). These particular sequences were confirmed by the observation of ROE interactions between protons involved in the interglycosidic linkages. Thus, the structure of saponin 1 is $24-O$-[ $\alpha$-L-rhamnopyranosyl-(1->2)- $\beta$ D-glucopyranosyl]-28-O-[ $\beta$-D-glucopyranosyl-(1->2)- $\beta$-D-glucopyranosyl]-protoaescigenin.

Formulae 1, 2 and $\mathbf{3}$ near here

Tables 1, 2 and 3 near here

Saponin 2 exhibited an intense $[\mathrm{M}+\mathrm{Na}]^{+}$ion peak at $\mathrm{m} / z, 1145$ in its positive ESI-MS and a molecular ion was detected at $\mathrm{m} / \mathrm{z}, 1121$ in the negative mode corresponding to a molecular formula 
of $\mathrm{C}_{54} \mathrm{H}_{90} \mathrm{O}_{24}\left(\mathrm{M}_{\mathrm{r}}\right.$ of 1122). All the fragmentations observed in the MS/MS ${ }^{\mathrm{n}}$ experiments followed the pattern observed in saponin $\mathbf{1}$, thus suggesting the similarity of the sugar chains and a missing oxygen atom in the genin (Table 1).

The lack of a substitution of C-16 in 2 was suggested by the absence of NMR signal for any deshielded signal for a $\mathrm{H}-16$ proton near $\delta 4.57 \mathrm{ppm}$ and by the replacement of the $\mathrm{C}-16$ hydroxymethine of $\mathbf{1}$ by a supplementary methylene at $\delta 42.2$ (Table 2). Thus the genin was identified as 16-desoxy-protoaescigenin. Proton and carbon spectra, and 2D NMR experiments (COSY, HSQC and HMBC) permitted assignments of all proton and carbon signals for four sugars (Table 3). The TOCSY and ROESY experiments indicated that the osidic chains of saponins 1 and 2 were identical. The structure of the new saponin 2 was deduced to be $24-O-[\alpha-\mathrm{L}-$ rhamnopyranosyl-(1->2)- $\beta$-D-glucopyranosyl]-28-O-[ $\beta$-D-glucopyranosyl-(1->2)- $\beta$-Dglucopyranosyl]-16-desoxy-protoaescigenin.

The positive ESI-MS of the new compound 3 gave a quasi-molecular ion at $\mathrm{m} / \mathrm{z} 1176 \mathrm{amu}$ $[\mathrm{M}+\mathrm{Na}+\mathrm{H}]^{+}$and the negative ESI-MS a molecular ion at $\mathrm{m} / z .1151$ in agreement with a molecular formula of $\mathrm{C}_{54} \mathrm{H}_{88} \mathrm{O}_{26}\left(\mathrm{C}_{54} \mathrm{H}_{90} \mathrm{O}_{25}\right.$ for saponin 1). The fragmentations were identical to those observed for saponins $\mathbf{1}$ and $\mathbf{2}$ and suggested the presence of the same osidic part (Table 1).

Comparison of the ${ }^{1} \mathrm{H}$ NMR spectra of compounds $\mathbf{1}$ and $\mathbf{3}$ showed signals for six angular methyl groups and for four hydroxymethine protons H-3, H-16, H-21 and H-22 in both compounds (Table 2) and absence of the AX spin system of H-24 protons in saponin 3. HMBC spectrum of saponin $\mathbf{3}$ displayed a correlation between $\mathrm{H}-23$ at $\delta 1.49 \mathrm{ppm}$ and one carbonyl at $\delta 175 \mathrm{ppm}$ suggesting that C-24 position of the genin was a carboxylic ester. The chemical shift of C-23 at $\delta 22.9$ also suggested that this methyl group was in an $\alpha$-equatorial position. The observation of ROE between $\alpha$-axial H-3 and H-23 confirmed the configuration of C-4 with a $\beta$-axial carboxylic ester C-24. The aglycone of saponin 3 was concluded to be the new $3 \beta, 16 \alpha, 21 \beta, 22 \alpha, 28 \beta$-pentahydroxy-olean12-en-24-oic acid named 24-oxo-camelliagenin D.

The ${ }^{1} \mathrm{H}$ and ${ }^{13} \mathrm{C}$ NMR spectra of $\mathbf{3}$ showed that this saponin contained four sugars with signals of 
anomeric carbons at $\delta_{\mathrm{C}} 93.9,96,102.1$ and 104 with corresponding anomeric protons at $\delta_{\mathrm{H}} 5.65$, 5.34, 4.24 and 4.66, respectively (Table 3). Analysis of 2D experiments (COSY, TOCSY and HSQC) permitted assignments of osidic ${ }^{1} \mathrm{H}$ and ${ }^{13} \mathrm{C}$ signals and identification of one $\beta$-D-glucose with shielded anomeric carbon $(\delta$ 93.9) and deshielded anomeric proton $(\delta 5.65)$ engaged in an ester linkage with the C-24 of genin, of one $\alpha$-L-rhamnose and of two $\beta$-D-glucoses. The ROESY experiment provided information about glycosidic linkages and showed that the sugar chains were identical as in saponins 1 and 2. Thus, saponin 3 was 24- $O$-[ $\alpha$-L-rhamnopyranosyl-(1->2)- $\beta$-Dglucopyranosyl]-28-O-[ $\beta$-D-glucopyranosyl-(1->2)- $\beta$-D-glucopyranosyl]-24-oxo-camelliagenin D.

These three compounds $\mathbf{1}, \mathbf{2}$ and $\mathbf{3}$ represent a new type of bidesmosidic triterpene saponins and to the best of our knowledge, the presence of a single sugar chain at C-24 instead of C-3 is unique.

The positive ESI-MS of compound 4 gave a quasi-molecular ion peak at $\mathrm{m} / z 693[\mathrm{M}+\mathrm{Na}]^{+}$ corresponding to a $\mathrm{M}_{\mathrm{r}}$ of 670 and a molecular formula of $\mathrm{C}_{40} \mathrm{H}_{62} \mathrm{O}_{8}$. The $\mathrm{MS}^{2}$ displayed two fragmentation peaks at $\mathrm{m} / \mathrm{z} 593$ and 493 corresponding to the losses of two $\mathrm{C}_{5} \mathrm{H}_{8} \mathrm{O}_{2}$ units, identified as angelic acids by analysis of ${ }^{1} \mathrm{H}$ and ${ }^{13} \mathrm{C}$ NMR spectra (Table 4) (Dizes et al., 1998).

The presence of protoaescigenin as aglycone in the structure of prosapogenin $\mathbf{4}$ was deduced from the analysis of its ${ }^{1} \mathrm{H}$ and ${ }^{13} \mathrm{C}$ NMR spectra (Table 4). The deshielded vicinal $\mathrm{H}-21$ and $\mathrm{H}-22$ protons at $\delta 5.80$ and 5.40 suggested that these positions were esterified by the angeloyl groups. HMBC experiment confirmed this assumption by the correlations observed between $\mathrm{H}-21\left(\delta_{\mathrm{H}} 5.80\right)$ and the carbonyl $\left(\delta_{\mathrm{C}} 167.5\right)$ of the first angeloyl group and between $\mathrm{H}-22\left(\delta_{\mathrm{H}} 5.40\right)$ and the carbonyl $\left(\delta_{\mathrm{C}} 169.2\right)$ of the second angeloyl residue. Prosapogenin 4 was identified as $21 \beta, 22 \alpha-O$-diangeloylprotoaescigenin previously described in Harpullia ramiflora (Dizes et al., 1998).

Formulae 4, 5 and 6 near here

Table 4 near here 
Compound 5 was characterised as $21 \beta, 22 \alpha$-O-diangeloyl barringtogenol C previously described in Aesculus indica ( Sati and Rana, 1987) and Maesa ramentacea (Tuntiwachwuttikul et al., 1997). Its positive ESI-MS showed a quasi-molecular ion $[\mathrm{M}+\mathrm{Na}]^{+}$at $\mathrm{m} / z, 677$ in agreement with a molecular formula of $\mathrm{C}_{40} \mathrm{H}_{62} \mathrm{O}_{7}$. The $\mathrm{MS}^{2}$ fragmentation gave two ion fragments at $\mathrm{m} / z 577$ and 477 attributed to the losses of two angelic acids as in prosapogenin 4. Comparison of ${ }^{1} \mathrm{H}$ NMR spectrum of compounds 4 and 5 indicated that 5 possessed one supplementary methyl singlet at $\delta 0.81$. In the ${ }^{13} \mathrm{C}$ NMR spectrum of 5 , only one hydroxymethylene was detected at $\delta 63.6(\mathrm{C}-28)$ and a supplementary methyl was observed at $\delta 15.8$ (Table 4). Consequently, the genin was identified as barringtogenol C (Ito and Ogino, 1967; Mahato and Kundu, 1994) also named theasapogenol B, which was substituted by two angeloyl groups on C-21 and C-22 in prosapogenin $\mathbf{5}$.

Prosapogenin 6 presented in positive ESI-MS an ion peak $[\mathrm{M}+\mathrm{Na}]^{+}$at $m / z 691\left(\mathrm{C}_{40} \mathrm{H}_{60} \mathrm{O}_{8}\right)$ and two ion fragments due to the losses of two angeloyl groups $(\mathrm{m} / z$ 591 and 491$)$. The ${ }^{1} \mathrm{H}$ and ${ }^{13} \mathrm{C}-\mathrm{NMR}$ spectra of prosapogenin $\mathbf{6}$ showed six quaternary methyls, two hydroxymethines at C-3 and C-16 positions, two hydroxymethines at C-21 and C-22 positions which were deshielded by esterification with angeloyl groups, one AX spin system $(\mathrm{H}-28)$ at $\delta_{\mathrm{H}} 2.92$ and $3.27(d, J=10.9 \mathrm{~Hz})$ and $\delta_{\mathrm{C}} 63.7$. Deshielded signals at $\delta_{\mathrm{H}} 9.80$ and $\delta_{\mathrm{C}} 207.9$ were detected and analysed for an aldehydic fonction at position C-24 (Table 4). The ROESY experiment confirmed this assignment with a ROE effect between axial H-3 and equatorial H-23 both in an $\alpha$-orientation. The configurations of C-16, C-21, C-22 and C-28 were consistent with those reported for camelliagenin D (Ito and Ogino, 1967). Thus, the new prosapogenin 6 was identified as $21 \beta, 22 \alpha-O$-diangeloyl camelliagenin D. Work is in progress to identify the saponins containing these prosapogenins.

\section{Experimental}


${ }^{1} \mathrm{H}$ and ${ }^{13} \mathrm{C}$ NMR spectra were recorded on Bruker Avance DRX $500\left({ }^{1} \mathrm{H}\right.$ at $500 \mathrm{MHz}$ and ${ }^{13} \mathrm{C}$ at $125 \mathrm{MHz}$ ); 2D experiments were performed using standard Bruker microprograms. ESI-MS and MS-MS experiments were recorded on Bruker Esquire LC-MS instrument. Optical rotations were measured on a Perkin-Elmer 241 Polarimeter.

\subsection{Plant material}

Stem bark of $H$. austro-caledonica was collected in rain forest at an elevation of $600 \mathrm{~m}$ in the reserve of Amieu Pass and Table Unio, New Caledonia, in March 1997. The specimen of the plant (LIT 0250) is deposited in the herbarium of the botanical laboratory at the CNRS centre of Noumea (New Caledonia).

\subsection{Extraction and isolation}

Dried and powered stem bark (1110 g) was macerated in 20\% aq. $\mathrm{MeOH}(10 \mathrm{l})$ for $17 \mathrm{~h}$ and boiled for $3 \mathrm{~h}$. The hydromethanolic extract was filtered, evaporated and freeze-dried to give a residue (106 g) which was suspended in $\mathrm{MeOH}(400 \mathrm{ml})$. The methanolic fraction was added to 21 of $\mathrm{Me}_{2} \mathrm{CO}$ and the ppt. was filtered and dried over $\mathrm{KOH}$ in vacuo. This dried ppt. $(57 \mathrm{~g})$ was dissolved in pure $\mathrm{H}_{2} \mathrm{O}$ and dialysed against $\mathrm{H}_{2} \mathrm{O}$ in seamless cellulose tubing under agitation during $48 \mathrm{~h}$. The contents of the tubes were freeze-dried to afford $32 \mathrm{~g}$ of a saponin mixt. (yield $3 \%$ ).

Two aliquotes of the saponin mixt. ( $1 \mathrm{~g}$ and $3 \mathrm{~g}$ ) were fractionated on a silica gel $\mathrm{CC}$, using a gradient of $\mathrm{CHCl}_{3}-\mathrm{MeOH}-\mathrm{H}_{2} \mathrm{O}(8: 2: 0$ to $15: 10: 1)$ for the first and $(7: 3: 0$ to $60: 40: 5)$ for the second. Frs. [15-21] of the first column and frs. [10-21] of the second column eluted with $\mathrm{CHCl}_{3}-\mathrm{MeOH}$ (7:3) were similar in comparing by TLC $\left(\mathrm{CHCl}_{3}-\mathrm{MeOH}-\mathrm{H}_{2} \mathrm{O}\right.$ 60:40:5) and were purified on a reversed-phase RP-18 CC using a gradient of $\mathrm{MeOH}-\mathrm{H}_{2} \mathrm{O}$ (55:45 to 8:2). Frs. [14-16] eluted with $\mathrm{MeOH}-\mathrm{H}_{2} \mathrm{O}(55: 45)$ was purified by preparative TLC in $\mathrm{CHCl}_{3}-\mathrm{MeOH}-\mathrm{H}_{2} \mathrm{O}$ (60:40:5) to give saponin 1 (7.8 mg). Frs. [19-29] eluted with (55:45), contained saponins 2 (4.7 mg) and 3 (2.4 mg), 
which were purified by silica gel CC eluted with $\mathrm{CHCl}_{3}-\mathrm{MeOH}-\mathrm{H}_{2} \mathrm{O}$ and followed by prep. TLC $\left(\mathrm{CHCl}_{3}-\mathrm{MeOH}-\mathrm{H}_{2} \mathrm{O}, 60: 40: 5\right)$.

\subsection{Saponin 1}

White powder. $[\alpha]_{\mathrm{D}}^{21^{\circ}}:-13.6^{\circ}\left(\mathrm{MeOH}, c\right.$ 0.45); ${ }^{1} \mathrm{H}$ and ${ }^{13} \mathrm{C}$ NMR $\left(\mathrm{CD}_{3} \mathrm{OD}\right)$ see Tables 2 and 3; ESI-MS (positive ion mode) m/z $1161[\mathrm{M}+\mathrm{Na}]^{+}$; ESI-MS-MS : $\mathrm{MS}^{2}$ (1161) m/z 1015 [(M+Na)rha $]^{+}, 997[(\mathrm{M}+\mathrm{Na})-\mathrm{glc}]^{+}, 853[(\mathrm{M}+\mathrm{Na})-\mathrm{rha}-\mathrm{glc}]^{+} ; \mathrm{MS}^{3}$ (1015) $\mathrm{m} / z 691$ [(M+Na)-rha-2glc $]^{+} ; \mathrm{ESI}-$ MS (negative ion mode) m/z 1137 [M-H]-, 991 [M-H-rha], 975 [M-H-glc]-; ESI-MS-MS : see Table 1.

\subsection{Saponin 2}

White powder. $[\alpha]_{\mathrm{D}}^{21^{\circ}}:-7.46^{\circ}(\mathrm{MeOH}, c 0.25) ;{ }^{1} \mathrm{H}$ and ${ }^{13} \mathrm{C}$ NMR $\left(\mathrm{CD}_{3} \mathrm{OD}\right)$ see Tables 2 and 3; ESI-MS (positive ion mode) $m / z, 1145[\mathrm{M}+\mathrm{Na}]^{+}$, ESI-MS-MS : $\mathrm{MS}^{2}$ (1145) m/z 999 [(M+Na)-

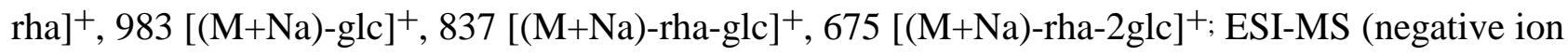
mode) $m / z, 1122\left[\mathrm{M}^{-\cdot}\right.$; ESI-MS-MS : see Table 1.

\subsection{Saponin 3}

White powder. $[\alpha]_{\mathrm{D}}^{21^{\circ}}: 0^{\circ}(\mathrm{MeOH}, c 0.108,) ;{ }^{1} \mathrm{H}$ and ${ }^{13} \mathrm{C}$ NMR $\left(\mathrm{CD}_{3} \mathrm{OD}\right)$ see Tables 2 and 3; ESIMS (positive ion mode) $m / z, 1176[\mathrm{M}+\mathrm{Na}+\mathrm{H}]^{+}$; ESI-MS-MS : $\mathrm{MS}^{2}$ (1176) $\mathrm{m} / z, 1129[(\mathrm{M}+\mathrm{Na})-$ rha $]^{+}, 867[(\mathrm{M}+\mathrm{Na})-\text { rha-glc }]^{+}, \mathrm{MS}^{3}(867) \mathrm{m} / z 705[(\mathrm{M}+\mathrm{Na})-\mathrm{rha}-2 \mathrm{glc}]^{+}, \mathrm{MS}^{4}$ (705) $\mathrm{m} / \mathrm{z} 543$ [genine+Na] ${ }^{+}$; ESI-MS (negative ion mode) $m / z 1152[\mathrm{M}]^{-\cdot}$; ESI-MS-MS : see Table 1.

\subsection{Acid hydrolysis of saponins}

The crude saponin $(500 \mathrm{mg})$ was dissolved in $16 \mathrm{ml}$ of a mixture (1:1) of $6.5 \% \mathrm{HClO}_{4}$ and $\mathrm{H}_{2} \mathrm{SO}_{4}$ $0.02 \mathrm{~N}$, and heated at $140^{\circ} \mathrm{C}$ in a sealed tube for $2 \mathrm{~h}$. After cooling, the sapogenin ppt. was filtered, rinsed with $\mathrm{H}_{2} \mathrm{O}$ and dried in vacuo over $\mathrm{P}_{2} \mathrm{O}_{5}$. The acid aq. layer was neutralised with $\mathrm{KOH} 0.5 \mathrm{M}$ 
and freeze-dried. Four sugars were identified with authentic samples by TLC in MeCOEt-isoPrOH-Me ${ }_{2} \mathrm{CO}-\mathrm{H}_{2} \mathrm{O}$ (20:10:7:6) as glucose, galactose, rhamnose and xylose. The sapogenin mixt. (260mg) was purified by silica gel $\mathrm{CC}$ using a gradient of $\mathrm{CHCl}_{3}-\mathrm{MeOH}$ (100:0 to 93:7) Prosapogenins 5 (3.7 mg) and 6 (3 mg) were found in frs. [7-13] eluted with $\mathrm{CHCl}_{3}$ and purified by silica gel CC using a gradient of hexane-AcOEt (9:1 to 7:3). Frs. [27-30] eluted with (99:1) contained prosapogenin 4 (33.2 $\mathrm{mg})$.

\subsection{1 $\beta, 22 \alpha$-O-diangeloyl protoaescigenin 4}

$[\alpha]_{\mathrm{D}}^{21^{\circ}}:+14.9^{\circ}\left(\mathrm{CHCl}_{3}, c 1\right) ;{ }^{1} \mathrm{H}$ and ${ }^{13} \mathrm{C} \mathrm{NMR}\left(\mathrm{CDCl}_{3}\right)$ see table 4; ESI-MS (positive ion mode)

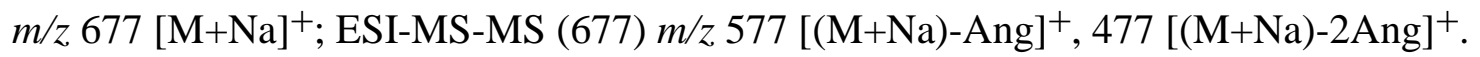

\section{9. $21 \beta, 22 \alpha$-O-diangeloyl barringtogenol $C 5$}

$[\alpha]_{\mathrm{D}}^{21^{\circ}}:+11^{\circ}\left(\mathrm{CHCl}_{3}, c 0.308\right) ;{ }^{1} \mathrm{H}$ and ${ }^{13} \mathrm{C}$ NMR $\left(\mathrm{CDCl}_{3}\right)$ see table 4; ESI-MS (positive ion

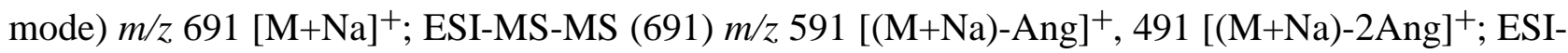
MS (negative ion mode) $\mathrm{m} / \mathrm{z} 667[\mathrm{M}-\mathrm{H}]^{-}$.

\subsection{0. $21 \beta, 22 \alpha$-O-diangeloyl camelliagenin D 6}

$[\alpha]_{\mathrm{D}}^{21^{\circ}}:+27^{\circ}\left(\mathrm{CHCl}_{3}, c 0.1\right) ;{ }^{1} \mathrm{H}$ and ${ }^{13} \mathrm{C} \mathrm{NMR}\left(\mathrm{CDCl}_{3}\right)$ see table 4; ESI-MS (positive ion mode)

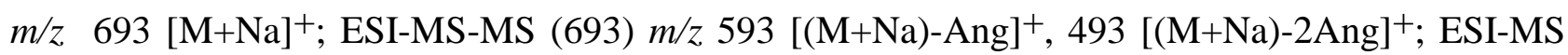
(negative ion mode) $\mathrm{m} / \mathrm{z} 669[\mathrm{M}-\mathrm{H}]^{-}$.

\section{Acknowledgments}

The authors are grateful to Dr T. Sevenet, ICSN, Gif-sur-Yvette, France, for providing plant material and to Dr G. Massiot, Laboratoires Pierre Fabre, France, for revising the manuscript and for arranging mass spectra. 


\section{References}

Chen, Y., Takeda, T., Ogihara Y., 1985. Studies on the constituents of Xanthoceras sorbifolia BUNGE. III. Minor Prosapogenins from the Fruits of Xanthoceras sorbifolia BUNGE. Chem. Pharm. Bull. 33, 127-134.

Dizes, C., Gerald, F., Lavaud, C., Elias, R., Faure, R., Massiot, G., 1998. Harpuloside a triterpenoid saponin from Harpullia ramiflora. Phytochemistry 48, 1229-1232.

Ito, S., Ogino, T., 1967. Two new triterpenes from Camellia sinensis and Camellia sasanqua. Tetrahedron Lett. 12, 1127-1132.

Mahato, S.B., Kundu, A.P., 1994. ${ }^{13}$ C NMR spectra of pentacyclic triterpenoids. A compilation and some salient features. Phytochemistry 37, 1517-1575.

Leenhouts, P. W., Vente, M., 1982. A taxonomic revision of Harpullia (Sapindaceae). Blumea 28, $1,1-52$.

Leenhouts, P. W., 1985. An attempt towards a natural system of Harpullia (Sapindaceae). Blumea $31,219-234$.

Sati, O.P., Rana, U., 1987. Triterpenoids of Aesculus indica. Pharmazie 42, 141.

Tuntiwachwuttikul, P., Pancharoen, O., Mahabusarakam, W., Wiriyachitra, P.,Taylor, W.C., Bubb, W.A., Towers, G.H.N., 1997. A triterpenoid saponin from Maesa ramentacea. Phytochemistry $44,491-495$. 

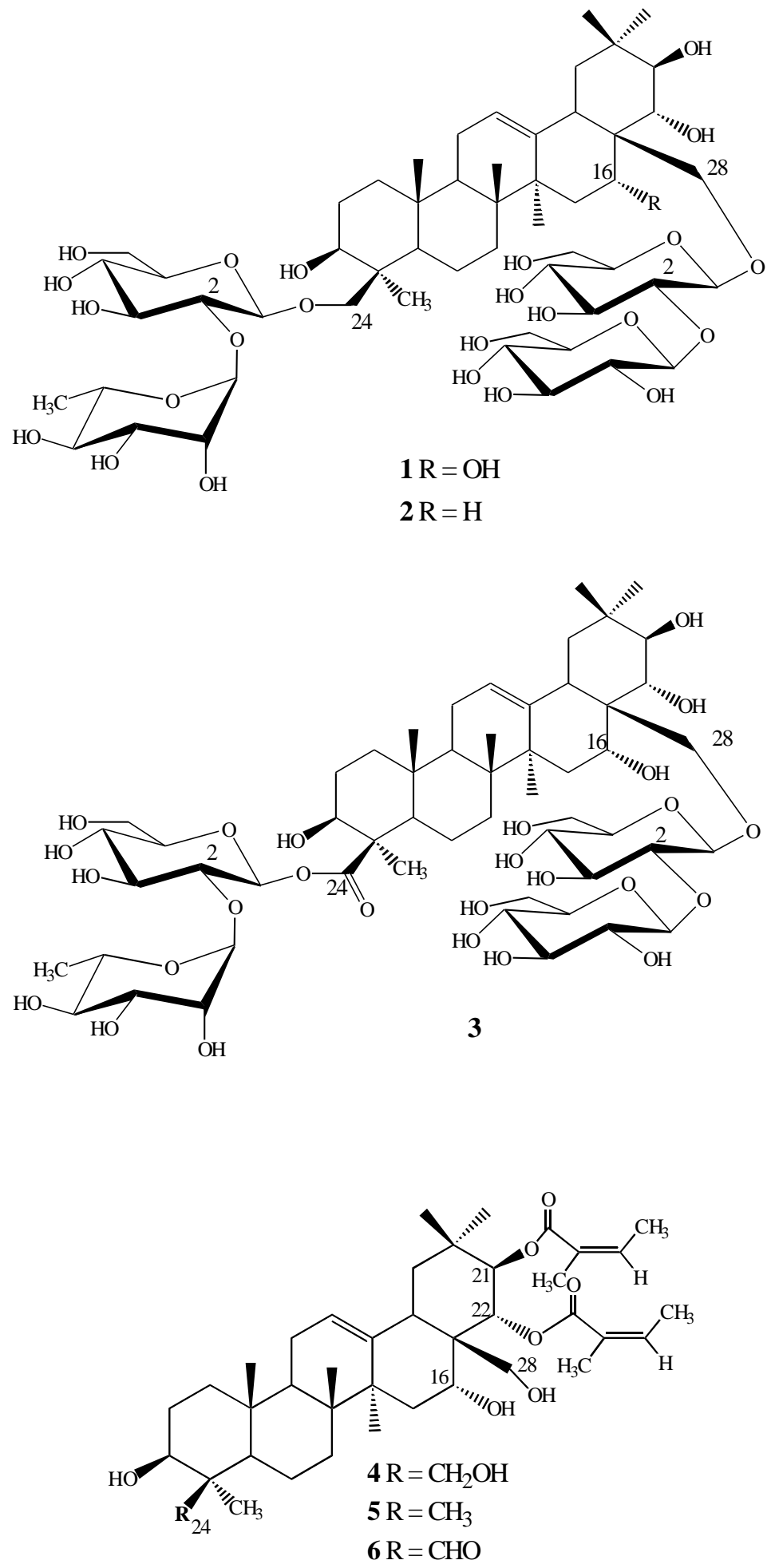
Table 1

ESI-MS and $\mathrm{MS}^{\mathrm{n}}$ data of saponins 1-3 $(\mathrm{m} / \mathrm{z})^{\mathrm{a}}$

\begin{tabular}{|c|c|c|c|c|}
\hline MS $^{n}$ (parent ion) & Fragments & 1 & 2 & 3 \\
\hline ESI-MS ${ }^{+}$ & {$[\mathrm{M}+\mathrm{Na}]^{+}$} & 1161 & 1145 & 1176 \\
\hline ESI-MS - & {$[\mathrm{M}-\mathrm{H}]^{-}$} & 1137 & $\begin{array}{c}1121 \\
\text { (obs. at 1122) }\end{array}$ & $\begin{array}{c}1151 \\
\text { (obs. at 1152) }\end{array}$ \\
\hline \multirow[t]{3}{*}{$\mathrm{MS}^{2}\left([\mathrm{M}-\mathrm{H}]^{-}\right)$} & {$[\mathrm{M}-\mathrm{H}-\mathrm{rha}]^{-}$} & 991 & 975 & - \\
\hline & {$[\mathrm{M}-\mathrm{H}-\mathrm{glc}]^{-}$} & 975 & 959 & 989 \\
\hline & {$[\mathrm{M}-\mathrm{H}-\mathrm{rha}-\mathrm{glc}]^{-}$} & 829 & 813 & 843 \\
\hline \multirow[t]{2}{*}{$\mathrm{MS}^{3}\left([\mathrm{M}-\mathrm{H}-\mathrm{rha}]^{-}\right)$} & {$[\mathrm{M}-\mathrm{H}-\mathrm{rha}-\mathrm{glc}]^{-}$} & 829 & 813 & \\
\hline & [M-H-rha-2glc $]^{-}$ & 667 & 651 & \\
\hline \multirow[t]{2}{*}{$\mathrm{MS}^{3}\left([\mathrm{M}-\mathrm{H}-\mathrm{glc}]^{-}\right)$} & {$[\mathrm{M}-\mathrm{H}-\mathrm{rha}-\mathrm{glc}]^{-}$} & 829 & & \\
\hline & [M-H-rha-2glc] ${ }^{-}$ & 667 & & \\
\hline \multirow[t]{2}{*}{$\mathrm{MS}^{3}\left([\mathrm{M}-\mathrm{H}-\mathrm{rha}-\mathrm{glc}]^{-}\right)$} & {$[\mathrm{M}-\mathrm{H}-\mathrm{rha}-2 \mathrm{glc}]^{-}$} & & & 681 \\
\hline & {$[\text { genin-H }]^{-}$} & & & 519 \\
\hline \multirow[t]{2}{*}{$\mathrm{MS}^{4}\left([\mathrm{M}-\mathrm{H}-\mathrm{rha}-\mathrm{glc}]^{-}\right)$} & [M-H-rha-2glc] ${ }^{-}$ & 667 & 651 & \\
\hline & [genin-H] $]^{-}$ & 505 & 489 & \\
\hline $\mathrm{MS}^{4}$ ([M-H-rha-2glc $\left.]^{-}\right)$ & [genin-H] $]^{-}$ & & & 519 \\
\hline
\end{tabular}

${ }^{a}$ rha, rhamnopyranosyl $\left(\mathrm{C}_{6} \mathrm{H}_{11} \mathrm{O}_{4}\right)$; glc, glucopyranosyl $\left(\mathrm{C}_{6} \mathrm{H}_{11} \mathrm{O}_{5}\right)$ 
Table 2

${ }^{1} \mathrm{H}$ and ${ }^{13} \mathrm{C}$ NMR data of genin part of saponins $\mathbf{1 - 3}$ in $\mathrm{CD}_{3} \mathrm{OD}$

\begin{tabular}{|c|c|c|c|c|c|c|c|c|c|c|c|c|}
\hline & \multicolumn{4}{|c|}{1} & \multicolumn{4}{|c|}{2} & \multicolumn{4}{|c|}{3} \\
\hline Genin & $\begin{array}{c}\delta \mathrm{H} \\
(\mathrm{ppm})\end{array}$ & $m$ & $J(\mathrm{~Hz})$ & $\begin{array}{c}\delta \mathrm{C} \\
(\mathrm{ppm})\end{array}$ & $\begin{array}{c}\delta \mathrm{H} \\
(\mathrm{ppm})\end{array}$ & $m$ & $J(\mathrm{~Hz})$ & $\begin{array}{c}\delta \mathrm{C} \\
(\mathrm{ppm})\end{array}$ & $\begin{array}{c}\delta \mathrm{H} \\
(\mathrm{ppm})\end{array}$ & $m$ & $J(\mathrm{~Hz})$ & $\begin{array}{c}\delta \mathrm{C} \\
(\mathrm{ppm})\end{array}$ \\
\hline $1 \mathrm{eq}$ & 1,70 & $m$ & - & 38.7 & 1.69 & $m$ & - & 38.5 & 1.77 & $m$ & - & 39 \\
\hline 1 ax & 1.03 & $m$ & - & & 1.03 & $m$ & - & & 1.10 & $m$ & - & \\
\hline $2 \mathrm{eq}$ & 1.64 & $m$ & - & 26.6 & 1.65 & $m$ & - & 26.6 & 1.69 & $d m$ & 12 & $n a^{\mathrm{a}}$ \\
\hline $2 \mathrm{ax}$ & 1.76 & $m$ & - & & 1.76 & $m$ & - & & 2.30 & $d d$ & $12 / 3.7$ & \\
\hline 3 & 3.27 & $d d$ & $12 / 4.8$ & 79 & 3.27 & $m$ & - & 79 & 3.17 & $d d$ & $12 / 4.5$ & 78.5 \\
\hline 4 & - & - & - & 42.6 & - & - & - & 42.6 & - & - & - & 49 \\
\hline 5 & 0.86 & $d$ & 8.3 & 56.1 & 0.93 & $d$ & 12 & 56 & 1.03 & $m$ & - & 56.7 \\
\hline $6 \mathrm{ax}$ & 1.61 & $m$ & - & 19.2 & 1.62 & $m$ & - & 19 & 1.84 & $m$ & - & $n a^{\mathrm{a}}$ \\
\hline $6 \mathrm{eq}$ & 1.75 & $m$ & - & & 1.76 & $m$ & - & & 1.58 & $m$ & - & \\
\hline $7 \mathrm{eq}$ & 1.42 & $m$ & - & 33 & 1.40 & $m$ & - & 33.8 & 1.42 & $m$ & - & $n a^{\mathrm{a}}$ \\
\hline $7 \mathrm{ax}$ & 1.59 & $m$ & - & & 1.54 & $m$ & - & & 1.60 & $m$ & - & \\
\hline 8 & - & - & - & 39.4 & - & - & - & 39.6 & - & - & - & 40 \\
\hline 9 & 1.68 & $m$ & - & 46.7 & 1.62 & $m$ & - & 47.7 & 1.66 & $d d$ & $15 / 8.5$ & 47 \\
\hline 10 & - & - & - & 36.5 & - & - & - & 36.5 & - & - & - & 37.1 \\
\hline 11 & 1.93 & $m$ & - & 23.5 & 1.94 & $m$ & - & 23.3 & 1.94 & $m$ & - & 23.5 \\
\hline 12 & 5.31 & $b r t$ & 3 & 122.9 & 5.27 & $b r t$ & 3.5 & 123.2 & 5.31 & $b r t$ & 3 & 123 \\
\hline 13 & - & - & - & 142.1 & - & - & - & 143 & - & - & - & 142.3 \\
\hline 14 & - & - & - & 41.1 & - & - & - & 41.4 & - & - & - & 41.2 \\
\hline $15 \mathrm{ax}$ & 1.89 & $d d$ & $15 / 4$ & 33 & - & - & - & 25 & 1.90 & $d d$ & $14.5 / 5$ & 32.7 \\
\hline $15 \mathrm{eq}$ & 1.43 & $d$ & 15 & - & - & - & - & & 1.44 & $d m$ & 14.5 & \\
\hline 16 & 4.57 & brs & $W_{1 / 2}=8$ & 66.3 & - & - & - & 42.2 & 4.58 & brs & $W_{1 / 2}=8$ & 66.3 \\
\hline 17 & - & - & - & 45.7 & - & - & - & $n a^{\mathrm{a}}$ & - & - & - & $n a^{\mathrm{a}}$ \\
\hline 18 & 2.18 & $d d$ & $13.5 / 4.5$ & 41.3 & 2.16 & $d d$ & $15 / 4.1$ & 41.5 & 2.17 & $d d$ & $14 / 7.7$ & 41.1 \\
\hline 19 ax & 2.52 & $t$ & 13.5 & 47.4 & 1.98 & $m$ & - & 46 & 2.51 & $t$ & 13.5 & 47.3 \\
\hline $19 \mathrm{eq}$ & 1.06 & $m$ & - & - & 1.15 & $d d$ & $14 / 4.1$ & & 1.05 & $d d$ & $13.5 / 4.5$ & \\
\hline 20 & - & - & - & 35.1 & - & - & - & 35.4 & - & - & - & 35.1 \\
\hline 21 & 3.95 & $d$ & 10 & 77.5 & 3.29 & $d$ & 10 & 76.2 & 3.95 & $d$ & 9.6 & 77.6 \\
\hline 22 & 3.79 & $d$ & 10 & 77.7 & 3.74 & $d$ & 10 & 76.2 & 3.79 & $d$ & 9.6 & 77.6 \\
\hline 23 & 1.22 & $s$ & - & 22.4 & 1.22 & $s$ & - & 22.4 & 1.49 & $s$ & - & 22.9 \\
\hline 24 & 4.13 & $d$ & 10 & 71.1 & 4.14 & $d$ & 10 & 70.7 & - & - & - & 175 \\
\hline $24^{\prime}$ & 3.67 & $d$ & 10 & - & 3.67 & $d$ & 10 & & & & & \\
\hline 25 & 1.04 & $s$ & - & 14.7 & 1.03 & $s$ & - & 14.6 & 0.96 & $S$ & - & 13 \\
\hline 26 & 0.97 & $s$ & - & 16 & 1.01 & $S$ & - & 15.9 & 0.99 & $s$ & - & 15.9 \\
\hline 27 & 1.44 & $S$ & - & 26 & 1.21 & $S$ & - & 25 & 1.45 & $S$ & - & 25.9 \\
\hline 28 & 3.66 & $d$ & 10 & 77 & 3.75 & $d$ & 10 & 75 & 3.65 & $d$ & 10.5 & 77.2 \\
\hline 28' & 3.45 & $d$ & 10 & - & 3.66 & $d$ & 10 & & 3.46 & $d$ & 10.5 & \\
\hline 29 & 0.97 & $s$ & - & 28.7 & 0.98 & $s$ & - & 28.6 & 0.93 & $s$ & - & 28.7 \\
\hline 30 & 0.94 & $S$ & - & 18 & 0.92 & $S$ & - & 17.8 & 0.97 & $S$ & - & 18 \\
\hline
\end{tabular}

a $n a:$ not assigned 
Table 3

${ }^{1} \mathrm{H}$ and ${ }^{13} \mathrm{C}-\mathrm{NMR}$ data of osidic part of saponins $\mathbf{1 - 3}$ in $\mathrm{CD}_{3} \mathrm{OD}$

\begin{tabular}{|c|c|c|c|c|c|c|c|c|c|c|c|c|}
\hline & \multicolumn{4}{|c|}{1} & \multicolumn{4}{|c|}{2} & \multicolumn{4}{|c|}{3} \\
\hline & $\begin{array}{c}\delta \mathrm{H} \\
(\mathrm{ppm})\end{array}$ & $m$ & $J(\mathrm{~Hz})$ & $\begin{array}{c}\delta \mathrm{C} \\
(\mathrm{ppm})\end{array}$ & $\begin{array}{c}\delta \mathrm{H} \\
(\mathrm{ppm})\end{array}$ & $m$ & $J(\mathrm{~Hz})$ & $\begin{array}{c}\delta \mathrm{C} \\
(\mathrm{ppm})\end{array}$ & $\begin{array}{c}\delta \mathrm{H} \\
(\mathrm{ppm})\end{array}$ & $m$ & $J(\mathrm{~Hz})$ & $\begin{array}{c}\delta \mathrm{C} \\
(\mathrm{ppm})\end{array}$ \\
\hline 24- $\beta$-D-Glucose & & & & & & & & & & & & \\
\hline 1 & 4.32 & $d$ & 7.7 & 102.4 & 4.32 & $d$ & 7.7 & 102.4 & 5.65 & $d$ & 7.6 & 93.9 \\
\hline 2 & 3.41 & $d d$ & $8.5 / 7.7$ & 77.8 & 3.42 & $d d$ & $8.4 / 7.7$ & 77.1 & 3.64 & $d d$ & $8.5 / 7.6$ & 76.8 \\
\hline 3 & 3.5 & $t$ & 8.5 & 77 & 3.5 & $t$ & 8.4 & 77.8 & 3.58 & $t$ & 8.5 & 77.8 \\
\hline 4 & 3.32 & $t$ & 8.5 & 70.6 & 3.31 & $t$ & 8.4 & 70.6 & 3.43 & $t$ & 8.5 & 70.2 \\
\hline 5 & 3.28 & $m$ & - & 76.8 & 3.29 & $m$ & - & 76.3 & 3.38 & $m$ & - & 76.4 \\
\hline 6 & 3.69 & $d d$ & $11.5 / 5.3$ & 61.4 & 3.7 & $d d$ & $11.5 / 6.9$ & 61.4 & 3.70 & $d d$ & $12 / 4.9$ & 61.2 \\
\hline $6^{\prime}$ & 3.89 & $d d$ & $11.5 / 1.6$ & & 3.89 & $d d$ & $11.5 / 2$ & & 3.82 & $d d$ & $12 / 2.3$ & \\
\hline$\underline{\alpha \text {-L-Rhamnose }}$ & & & & & & & & & & & & \\
\hline 1 & 5.38 & $d$ & 1.3 & 100 & 5.38 & $d$ & 1.3 & 100 & 5.34 & $d$ & 1.5 & 96 \\
\hline 2 & 3.95 & $d d$ & $3.2 / 1.8$ & 70.6 & 3.93 & $d d$ & $3.3 / 1.8$ & 70.6 & 3.95 & $m$ & - & 70.8 \\
\hline 3 & 3.76 & $d d$ & $9.3 / 3.2$ & 70.4 & 3.77 & $d d$ & $9.4 / 3.3$ & 70.5 & 3.68 & $d d$ & $10 / 1.5$ & 70.5 \\
\hline 4 & 3.38 & $t$ & 9.3 & 72.8 & 3.38 & $t$ & 9.4 & 72.8 & 3.39 & $t$ & 10 & 72.5 \\
\hline 5 & 3.98 & $m$ & - & 68.6 & 3.97 & $d q$ & $9.4 / 6.2$ & 68.6 & 3.78 & $m$ & - & 68.8 \\
\hline 6 & 1.29 & $d$ & 6 & 16.9 & 1.29 & $d$ & 6.2 & 16.9 & 1.27 & $d$ & 6.5 & 16.9 \\
\hline 28- $\beta$-D-Glucose & & & & & & & & & & & & \\
\hline 1 & 4.23 & $d$ & 7.7 & 101.7 & 4.31 & $d$ & 7.8 & 101.7 & 4.24 & $d$ & 7.6 & 102.1 \\
\hline 2 & 3.47 & $d d$ & $9.1 / 7.7$ & 80.3 & 3.5 & $d d$ & $9.1 / 7.8$ & 80.3 & 3.47 & $d d$ & $9 / 7.6$ & 80.4 \\
\hline 3 & 3.58 & $t$ & 9.1 & 76.7 & 3.59 & $t$ & 9.1 & 76.7 & 3.58 & $t$ & 9 & 76.7 \\
\hline 4 & 3.35 & $t$ & 9.1 & 69.8 & 3.37 & $t$ & 9.1 & 69.8 & 3.35 & $m$ & - & 69.8 \\
\hline 5 & 3.23 & $m$ & - & 72.8 & 3.26 & $m$ & - & 72.8 & 3.24 & $m$ & - & 74.5 \\
\hline 6 & 3.69 & $d d$ & $11.7 / 5.3$ & 61.1 & 3.72 & $d d$ & $12 / 6.2$ & 61.1 & 3.68 & $d d$ & $11.8 / 5$ & 61.2 \\
\hline $6^{\prime}$ & 3.86 & $d d$ & $11.7 / 1.9$ & & 3.87 & $d d$ & $12 / 2$ & & 3.86 & $d d$ & $11.8 / 2.3$ & - \\
\hline -D-D-Glucose & & & & & & & & & & & & \\
\hline 1 & 4.66 & $d$ & 7.8 & 103.4 & 4.68 & $d$ & 7.8 & 103.3 & 4.66 & $d$ & 7.8 & 104 \\
\hline 2 & 3.24 & $t$ & 7.8 & 76.5 & 3.21 & $d d$ & $10.5 / 7.8$ & 73.9 & 3.24 & $t$ & 7.8 & 76.5 \\
\hline 3 & 3.40 & $m$ & - & 76.5 & 3.38 & $m$ & - & 76.5 & 3.39 & $m$ & - & 76.6 \\
\hline 4 & 3.41 & $m$ & - & 69.5 & 3.32 & $m$ & - & 69.5 & 3.28 & $m$ & - & 69.4 \\
\hline 5 & 3.27 & $m$ & - & 76.3 & 3.26 & $m$ & - & 76.8 & 3.41 & $m$ & - & 76.9 \\
\hline 6 & 3.92 & $d d$ & $10.6 / 1.6$ & 60.6 & 3.89 & $d d$ & $11.5 / 6$ & 60.8 & 3.92 & $d d$ & $12 / 1.6$ & 60.6 \\
\hline $6^{\prime}$ & 3.76 & $d d$ & $11 / 5$ & & 3.74 & $d d$ & $11.5 / 2$ & & 3.76 & $d d$ & $12 / 4.6$ & - \\
\hline
\end{tabular}


Table 4

${ }^{1} \mathrm{H}$ and ${ }^{13} \mathrm{C}$ NMR data of prosapogenins 4-6 in $\mathrm{CDCl}_{3}$

\begin{tabular}{|c|c|c|c|c|c|c|c|c|c|c|c|c|}
\hline & \multicolumn{4}{|c|}{4} & \multicolumn{4}{|c|}{5} & \multicolumn{4}{|c|}{6} \\
\hline Genin & $\begin{array}{c}\delta \mathrm{H} \\
(\mathrm{ppm})\end{array}$ & $m$ & $J(\mathrm{~Hz})$ & $\begin{array}{c}\delta \mathrm{C} \\
(\mathrm{ppm})\end{array}$ & $\begin{array}{c}\delta \mathrm{H} \\
(\mathrm{ppm})\end{array}$ & $m$ & $J(\mathrm{~Hz})$ & $\begin{array}{c}\delta \mathrm{C} \\
(\mathrm{ppm})\end{array}$ & $\begin{array}{c}\delta \mathrm{H} \\
(\mathrm{ppm})\end{array}$ & $m$ & $J(\mathrm{~Hz})$ & $\begin{array}{c}\delta \mathrm{C} \\
(\mathrm{ppm})\end{array}$ \\
\hline $1 \mathrm{eq}$ & 1.65 & $m$ & - & 38.3 & 1.67 & brd & 13 & 38.5 & 1.75 & $b r d$ & 13 & 38.4 \\
\hline $1 \mathrm{ax}$ & 0.98 & $d d d$ & $17 / 13 / 7$ & & 1.02 & $m$ & - & & 1.07 & $m$ & - & \\
\hline $2 \mathrm{eq}$ & 1.70 & $d d$ & $13 / 3.7$ & 27.5 & 1.62 & $m$ & - & 27.1 & 1.86 & $m$ & - & 28 \\
\hline $2 \mathrm{ax}$ & 1.81 & $m$ & - & & 1.59 & $m$ & - & & 1.87 & $m$ & - & \\
\hline 3 & 3.44 & $d d$ & $11.6 / 4.2$ & 80.6 & 3.25 & $d d$ & $12 / 5.2$ & 78.9 & 3.23 & $d d$ & $14 / 6.5$ & $n a^{\mathrm{a}}$ \\
\hline 4 & - & - & - & 42.6 & - & - & - & 38.7 & - & - & - & 52.6 \\
\hline 5 ax & 0.86 & $d$ & 14.5 & 55.7 & 0.77 & $d$ & 11.4 & 55.1 & 1.03 & $d$ & 13.6 & 56.3 \\
\hline $6 \mathrm{ax}$ & 1.29 & $m$ & - & 18.3 & 1.42 & $m$ & - & 18.2 & 1.64 & $m$ & - & 18.3 \\
\hline $6 \mathrm{eq}$ & 1.61 & $m$ & - & & 1.58 & $m$ & - & & 1.88 & $m$ & - & \\
\hline $7 \mathrm{ax}$ & 1.54 & $m$ & - & 32.9 & 1.59 & $m$ & - & 32.7 & 1.58 & $m$ & - & 32.9 \\
\hline 7 eq & 1.30 & $m$ & - & & 1.31 & $m$ & - & & 1.41 & $m$ & - & \\
\hline 8 & - & - & - & 39.6 & - & - & - & 39.7 & - & - & - & 39.5 \\
\hline 9 & 1.62 & $m$ & - & 46.5 & 1.65 & $m$ & - & 46.5 & 1.66 & $m$ & - & 45.4 \\
\hline 10 & - & - & - & 36.5 & - & - & - & 36.8 & - & - & - & 37.1 \\
\hline 11 & 1.89 & $m$ & - & 23.7 & 1.93 & $m$ & - & 23.4 & 1.95 & $m$ & - & 23.8 \\
\hline 12 & 5.44 & $b r t$ & 3.5 & 124.5 & 5.48 & $b r t$ & 3.4 & 124.7 & 5.48 & $t$ & 3.5 & 124.6 \\
\hline 13 & - & - & - & 140.7 & - & - & - & 140.7 & - & - & - & 140.8 \\
\hline 14 & - & - & - & 40.9 & - & - & - & 40.9 & - & - & - & 41.1 \\
\hline 15 ax & 1.65 & $d d$ & $15.3 / 3.5$ & 33.5 & 1.70 & $d d$ & $15 / 4$ & 33.6 & 1.69 & $d d$ & $15 / 1.7$ & 33.5 \\
\hline $15 \mathrm{eq}$ & 1.35 & $d d$ & $15.3 / 1.5$ & & 1.38 & $d m$ & 15 & & 1.40 & $d d$ & $15 / 4$ & \\
\hline 16 & 3.94 & brs & $W_{1 / 2}=8$ & 69.6 & 3.97 & brs & $W_{1 / 2}=11$ & 69.8 & 3.96 & $b r s$ & $W_{1 / 2}=10$ & 69.8 \\
\hline 17 & - & - & - & 47.7 & & & - & 47.7 & & - & - & 47.8 \\
\hline 18 ax & 2.72 & $d d$ & $14 / 4.1$ & 39.2 & 2.75 & $d d$ & $14 / 4$ & 39.2 & 2.74 & $d d$ & $14 / 4$ & 39.3 \\
\hline 19 ax & 2.57 & $t$ & 14 & 46.3 & 2.59 & $t$ & 14 & 46.3 & 2.56 & $t$ & 14 & 46.3 \\
\hline $19 \mathrm{eq}$ & 1.26 & $d d$ & $14 / 4$ & & 1.30 & $d d$ & $14 / 4$ & & 1.31 & $d d$ & $14 / 4$ & \\
\hline 20 & & - & - & 35.7 & & & - & 35.7 & & - & - & 35.8 \\
\hline 21 & 5.80 & $d$ & 10.3 & 77.4 & 5.88 & $d$ & 10.3 & 77.3 & 5.85 & $d$ & 10.3 & 77.2 \\
\hline 22 & 5.40 & $d$ & 10.3 & 73.1 & 5.43 & $d$ & 10.3 & 73.1 & 5.42 & $d$ & 10.3 & 73.1 \\
\hline 23 & 1.24 & $s$ & - & 22.4 & 1.11 & $s$ & - & 28 & 1.30 & $s$ & - & 19.1 \\
\hline 24 & 4.19 & $d$ & 11 & 64.4 & 0.81 & $s$ & - & 15.8 & 9.80 & $s$ & - & 207.9 \\
\hline $24^{\prime}$ & 3.32 & $d$ & 11 & & & & & & & & & \\
\hline 25 & 0.88 & $s$ & - & 16.1 & 0.94 & $s$ & - & 14.1 & 0.87 & $s$ & - & 14.7 \\
\hline 26 & 0.86 & $s$ & - & 16.6 & 0.95 & $s$ & - & 16.7 & 0.93 & $s$ & - & 16.8 \\
\hline 27 & 1.44 & $s$ & - & 26.9 & 1.47 & $s$ & - & 27 & 1.46 & $s$ & - & 26.9 \\
\hline 28 & 3.26 & $d$ & 11 & 63.5 & 3.29 & $d$ & 10 & 63.6 & 3.27 & $d$ & 10.9 & 63.7 \\
\hline $28 '$ & 2.89 & $d$ & 11 & & 2.92 & $d$ & 10 & & 2.92 & $d$ & 10.9 & \\
\hline 29 & 0.91 & $s$ & - & 29 & 0.92 & $s$ & - & 29 & 0.93 & $s$ & - & 29 \\
\hline 30 & 1.08 & $s$ & - & 19.5 & 1.02 & $s$ & - & 19.5 & 1.09 & $s$ & - & 19.5 \\
\hline \multicolumn{13}{|l|}{ Angeloyls } \\
\hline $1^{\prime}$ & - & - & - & 167.5 & - & - & - & 167.5 & - & - & - & 167.6 \\
\hline $2^{\prime}$ & - & - & - & 128 & - & - & - & 128 & - & - & - & 128 \\
\hline $3^{\prime}$ & 6.01 & $q q$ & $7.3 / 1.3$ & 137.5 & 6.03 & $q q$ & $7.3 / 1.3$ & 137.5 & 6.02 & $q q$ & $7.3 / 1.5$ & 137.6 \\
\hline $4^{\prime}$ & 1.92 & $d q$ & $7.3 / 1.3$ & 15.5 & 1.95 & $d q$ & $7.3 / 1.3$ & 15.5 & 1.93 & $d q$ & $7.3 / 1.5$ & 15.6 \\
\hline $5^{\prime}$ & 1.82 & $q$ & 1.3 & 20.4 & 1.85 & $q$ & 1.3 & 20.4 & 1.83 & $q$ & 1.5 & 20.4 \\
\hline 1" & - & - & - & 169.2 & - & - & - & 169.2 & - & - & - & 169.2 \\
\hline 2" & - & - & - & 127 & - & - & - & 127 & - & - & - & 127 \\
\hline 3" & 6.11 & $q q$ & $7.2 / 1.4$ & 140.1 & 6.14 & $q q$ & $7.2 / 1.4$ & 140.1 & 6.13 & $q q$ & $7.2 / 1.5$ & 140.3 \\
\hline 4" & 1.95 & $d q$ & $7.2 / 1.4$ & 15.5 & 1.98 & $d q$ & $7.2 / 1.4$ & 15.5 & 1.97 & $d q$ & $7.2 / 1.5$ & 15.8 \\
\hline 5" & 1.82 & $q$ & 1.4 & 20.6 & 1.85 & $q$ & 1.4 & 20.6 & 1.83 & $q$ & 1.5 & 20.6 \\
\hline
\end{tabular}

${ }^{\mathrm{a}}$ na $:$ not assigned 